\title{
Rum, Sodomy, Prayers, and the Lash Revisited: Winston Churchill and Social Reform in the Royal Navy, 1900-1915
}

Review Number: 2291

Publish date: Thursday, 15 November, 2018

Author: Matthew Seligmann

ISBN: 9780198759973

Date of Publication: 2018

Price: $£ 60.00$

Pages: 208pp.

Publisher: Oxford University Press

Publisher url: https://global.oup.com/academic/product/rum-sodomy-prayers-and-the-lash-revisited9780198759973 ?cc $=$ gb\&lang=en\&

Place of Publication: Oxford

Reviewer: David G. Morgan-Owen

As is often the case with (in)famous remarks attributed to prominent personages, there is some doubt about whether Winston Churchill ever did describe the traditions of the Royal Navy as comprising 'nothing but rum, sodomy, prayers and the lash.' Churchill himself reputedly denied that he had, confiding to his private secretary that 'I never said it. I wish I had' (p. 1). His regret is easy to understand, for this list has become the most convenient shorthand for encapsulating the mythical tenets of the tradition which governed the lives of the Royal Navy's sailors, and of explaining Churchill's attitude towards it. Yet, as Matthew Seligmann demonstrates in this thoroughly researched and readable book, Churchill and his naval colleagues dedicated a great deal of time and effort to updating the policies which governed the social life of the Royal Navy in the early twentieth century. Their efforts in doing so confound stereotypes of a staunchly conservative and doctrinaire Service, and of Churchill as having abandoned his Radical credentials during his period as First Lord of the Admiralty between 1911 and 1915.

Historians have been quick to blame the Royal Navy's traditions for many of the shortcomings they have identified in the Service's thinking and performance during this period. The 'long calm lee of Trafalgar', in which the Navy apparently ossified into a caricature of itself - more interested in polishing brass work than thinking seriously about war - has become a well entrenched trope. In earlier works Seligmann has played a leading role in challenging this depiction of a 'somnolent' Royal Navy, unable to shake the legacy of its past glory. In this new book, he addresses the manner in which Their Lordships of the Admiralty sought to shape and modernise the policies and practices which shaped the social world of the Royal Navy in the earlier twentieth century, and to highlight the role which a young Winston Churchill played in this process between 1911 and 1915.

This is a significant and innovative approach for two reasons. First and foremost, it is a subject which has received remarkably little attention from historians of the Royal Navy in general, and of this period in particular. Excellent social histories of the lower deck and elements of the officer corps have been produced, to which one might add recent research on morale,[1] [2] however no attempt has been made to systematically chart how the Admiralty itself sought to regulate the life of the Navy's sailors. Seligmann has 
thus set out to answer a new question, and one which has interesting broader ramifications for our understanding of the British state as a whole in this period. As Patrick Joyce has argued in his 'social history of the British state',[2] [3] the ways in which state control manifest itself in the everyday life of its subjects provides a revealing and significant insight into the state itself. Joyce focuses his attention on the Post Office, but Seligmann's example provides an interesting contrast, for the Royal Navy exercised a much more overt control over the lives of its sailors. How it treated them offers a new window into standards of morality, decency, and tolerance in contemporary Britain, and how those standards interacted with the demands of military life.

Beyond seeking to answer a new question, this book also sets about answering it in a unique way. The naval records of this period have been subject to numerous rounds of 'weeding', [3] [4] which has left only a tiny portion of the otherwise burgeoning original Admiralty archive. Seligmann has succeeded in developing a deeply impressive, systematic understanding of the surviving material, such that he has been able to locate and in some cases reconstruct otherwise lost documents from fragments preserved elsewhere (a process detailed in a short but helpful essay on sources on pages 169-75). This has enabled him to research an account that would have been almost impossible for most other historians to have pieced together, a feat which must be recognised as impressive in its own right, before one even gets to grips with the contents of this work.

The book is arranged thematically, with chapters addressing pay and democratization, rum, sodomy, religion, and corporal punishment. Each examines Admiralty social policy from the early twentieth century onwards, enabling Churchill's contribution to be set against its proper backdrop, and allowing changes in policy and attitude over time to become clear. The picture that emerges is a mixed one. In certain areas, Admiralty social policy appeared to be comparatively enlightened for the time. This was particularly true when it came to making provision for non-conformist religious worship, and limiting the application of corporal punishment to boy sailors (although not banning it altogether). Elsewhere, more retrograde attitudes remained prevalent. This period witnessed the Admiralty experiencing something of a moral crisis over homosexuality in the Navy, one official noting that Their Lordships 'cannot avoid the conclusion that unnatural offences are prevalent in the Service to a much greater extent than is generally believed' (p. 95). This resulted in a tightening up of the legal framework surrounding homosexual behaviour, and the employment of medical officers in rooting out men partaking in same-sex relations.

Churchill's role in these reforms has often been either overlooked, or characterised in mildly negative terms. This depiction can no longer be sustained. Seligmann convincingly demonstrates that the enthusiasm for social reform which Churchill had shown prior to arriving at the Admiralty not only accompanied him to his new office in 1911, but that he enjoyed significant (if not total) success in his efforts to improve the lives of ordinary sailors in the Royal Navy. Having something genuinely new to say about Winston Churchill in 2018 is no small achievement, and Seligmann must be judged to have done so in a highly impressive and balanced manner.

Overall, this is a well-written, accessible book which will appear to naval and social historians, as well as to Churchill scholars more broadly.

[1] [5] L. Rowe, Morale and Discipline in the Royal Navy in the First World War (Cambridge, 2018).

[2] [6] P. Joyce, The State of Freedom: A Social History of the British State since 1800 (Cambridge, 2013).

[3] [7] M.S. Seligmann, 'A great American scholar of the Royal Navy? The disputed legacy of Arthur Marder revisited', The International History Review, 38, 5 (2016), 1040-54. 
Source URL:https://reviews.history.ac.uk/review/2291

\section{Links}

[1] https://reviews.history.ac.uk/item/298830

[2] https://uolonlinemy.sharepoint.com/personal/danny_millum_sas_ac_uk/Documents/Reviews/current\%20reviews\%20for\%20editing/ [3] https://uolonlinemy.sharepoint.com/personal/danny_millum_sas_ac_uk/Documents/Reviews/current\%20reviews\%20for\%20editing/ [4] https://uolonlinemy.sharepoint.com/personal/danny_millum_sas_ac_uk/Documents/Reviews/current\%20reviews\%20for\%20editing/ [5] https://uolonlinemy.sharepoint.com/personal/danny_millum_sas_ac_uk/Documents/Reviews/current\%20reviews\%20for\%20editing/ [6] https://uolonlinemy.sharepoint.com/personal/danny_millum_sas_ac_uk/Documents/Reviews/current\%20reviews\%20for\%20editing/ [7] https://uolonlinemy.sharepoint.com/personal/danny_millum_sas_ac_uk/Documents/Reviews/current\%20reviews\%20for\%20editing/r 